\title{
EDITORIAL
}

\section{IDESIA: ¿qué publica?}

\author{
IDESIA: what does it publish?
}

Dr. German F. Sepúlveda Chavera Departamento de Recursos Ambientales Universidad de Tarapacá Arica-Chile gsepulve@uta.cl

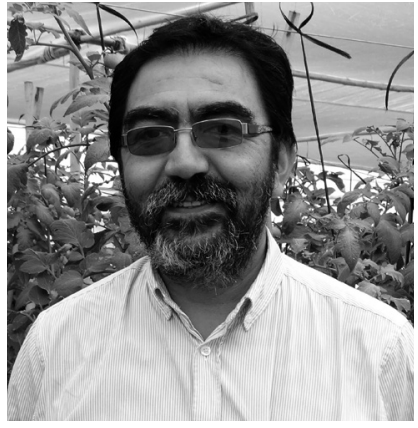

PhD. German F. Sepúlveda Chavera Department of Environmental Resources University of Tarapaca Arica-Chile @ uta.cl
Revista IDESIA es una publicación científica con más de 40 años de trayectoria, depositaria del conocimiento sistemático en ciencias agropecuarias, ambientales y afines de zonas áridas, inicialmente generada en el Centro de Investigación y Capacitación Agrícola -CICA- actual Facultad de Ciencias Agronómicas. En el primer número de agosto de 1970 publicó 10 trabajos inéditos y cinco notas científicas, distribuidas en 170 páginas. El 80\% de este primer volumen se relacionó con manejo fitosanitario, incluyendo evaluación de insecticidas, acaricidas y la descripción de nuevas plagas. El segundo volumen de marzo de 1972 incorporó el resultado de nueve trabajos y cuatro notas científicas. Además, publicó trabajos pioneros en patología vegetal. Desde esos primeros números, la revista mostró su orientación, constituyéndose en una publicación seriada de connotación. Se incrementó la frecuencia de publicación y la dinámica de las investigaciones, permitió presentar resultados de investigaciones de otras instituciones nacionales e internacionales. De 2001 a 2005 se publicaron dos números por año, y desde 2006 a 2012 se agregó un nuevo número. Desde 2013, en un nuevo esfuerzo editorial, se publican cuatro números por año, con un promedio de 125 páginas por número. Desde 2010 a la fecha se publican 123,8 páginas promedio por número. Brasil es el país extranjero que reúne mayor número de trabajos publicados, evidenciando que IDESIA amplió el espectro de
The journal IDESIA is a scientific publication with more than 40 years of history. It is a depository of systematic knowledge in agricultural, environmental and related sciences of arid zones; it was originally generated in the Centro de Investigación y Capacitación Agrícola -CICA- currently the Facultad de Ciencias Agronómicas. The first issue, in August, 1970, included 10 articles of original research and five scientific notes in a total of 170 pages. Eighty percent of this first number was related to phytosanitary management, including evaluation of insecticides, acaricides and the description of new pests. The second volume, in March, 1972 included nine articles and four scientific notes. It also published pioneer studies in plant pathology. In these first numbers the journal already showed its orientation; it has become a well-known serial publication. The publication frequency was increased and the dynamics of research allowed it to include results of research of other national and international institutions. There were two numbers per year from 2001 to 2005; a third number was added in 2006-2012. Increasing editorial effort, beginning in 2013 the journal publishes four numbers per year, with a mean of 125 pages per number. From 2010 to the present there has been an average of 123.8 pages per number. Brazil is the foreign country which has most published papers, showing that IDESIA 
publicación, incorporando trabajos de otras zonas del planeta. Las normas de publicación de IDESIA son claras y apuntan a definir un nivel de calidad determinado por la rigurosidad científica, metodológica, semántica y gramatical. La información científica contenida en IDESIA se concentra en fitosanidad, con $36 \%$ de los artículos publicados, de los cuales $26,1 \%$ de los trabajos se refieren a entomología, $4,9 \%$ a patología vegetal, la misma proporción se refiere a nematología agrícola, $0,6 \%$ a malezas, $10,1 \%$ a hortalizas, $7,4 \%$ se refieren a fruticultura, y en los últimos años se incorporaron temas ambientales, los que representan el 8,6\%. Otros temas publicados en la revista se refieren a riego, suelos, biotecnología y políticas agrarias y comercio. Estos trabajos científicos conforman un total de 770 artículos publicados que ocupan 6.806 páginas editadas desde 1970 hasta 2016.

La literatura científica abarca publicaciones que se basan en trabajos experimentales y teóricos originales en las diferentes disciplinas de las ciencias. IDESIA canaliza trabajos eminentemente experimentales, exploratorios y transeccionales. Ha evolucionado desde un enfoque profesional hacia una vertiente académica de acuerdo a la tipología propuesta por Mc Donald y Feather (1995), presentando resultados de investigaciones propias de agricultura de zonas áridas enfocadas hacia la comunidad científica y académica. En la actualidad, cada trabajo sometido a IDESIA pasa por una rigurosa revisión en donde se analizan aspectos formales, de contexto, hipótesis, objetivos, aspectos metodológicos y la coherencia en la presentación de novedades científico-técnicas. El trabajo de los revisores -árbitros o pares evaluadores- no es marginal, por el contrario, desde la imparcialidad y bajo los mejores estándares científicos a la luz del conocimiento actualizado, deben juzgar la validez científica y metodológica de la publicación. De esta manera, la calidad de una revista científica refleja la experiencia y rigurosidad de quienes ejercen funciones anónimas de arbitraje. La ecuanimidad y el valor de la información inédita a la que tienen acceso los árbitros se traducen en la rigurosa confidencialidad guardada por el equipo editorial. Si bien es cierto, existen formatos específicos de evaluación para los manuscritos, la evaluación debe reconocer los defectos y méritos del mismo observando estrategias para mejorar el manuscrito y presentar las críticas de manera objetiva e imparcial, sin juicios peyorativos. El revisor es un ente colaborativo, widened its publication spectrum, incorporating studies from other zones of the planet. The publication norms of IDESIA are clear; they aim to define a level of quality that includes scientific, methodological, semantic and grammatical rigor. The scientific information contained in IDESIA is most concentrated in phytosanitary studies (36\%); of these $26.1 \%$ are in entomology, $4.9 \%$ in plant pathology and agricultural nematology, $0.6 \%$ in weeds, $10.1 \%$ in vegetables, and $7.4 \%$ in fruit culture. In recent years environmental studies have been incorporated, which now represent $8.6 \%$. Other areas published in the journal include irrigation, soils, biotechnology, agricultural policies and commerce. There are a total of 770 scientific studies published, which occupy the 6806 pages published between 1970 and 2016.

The scientific literature includes publications based on original theory and experimental studies in the different disciplines of the sciences. IDESIA channels eminently experimental, exploratory and trans-sectional studies. It has evolved from a professional focus to an academic one, according to the typology proposed by McDonald and Feather (1995), presenting the results of agricultural research in arid zones, focused on the scientific and academic community. Currently, each manuscript submitted to IDESIA must pass a rigorous review that analyzes formal aspects, context, hypotheses, objectives, methodological aspects and the coherence in the presentation of scientific-technical novelties. The labor of the reviewers -arbiters and peer evaluators- is important, since they evaluate impartially using highest scientific standards based on current knowledge, judging the scientific and methodological validity of the study. The quality of a scientific journal reflects the experience and rigor of those who perform the anonymous job of being arbiters. The equanimity and the value of the unpublished information to which the referees have access is reflected in the rigorous confidentiality maintained by the editorial team. Although there are specific evaluation formats for manuscript evaluation, this evaluation should recognize the merits and defects of the manuscript, observing strategies to improve it and presenting criticisms objectively and impartially, without pejorative judgements. The reviewer is a collaborator, who must always 
que considera siempre el rigor y excelencia de la revista con la cual trabaja. Una vez aceptado el trabajo, se cumple con uno de los requisitos del método científico: difusión de información inédita. Para IDESIA, los desafíos son crecientes, existen nuevos canales de información, redes profesionales dinámicas, en donde la información fluye y se debe responder a los criterios de calidad científica, basada en la rigurosidad del trabajo arbitral. IDESIA se encuentra abierta a la publicación de artículos científicos internacionales y tiene amplia presencia en diferentes bases de datos (CAB, SciELO, Dialnet, por citar algunas). De esta forma y a diferencia de lo que plantean Contreras y colaboradores (2015), los trabajos se proyectan fuera de las fronteras y se potencia, por tanto, la mayor circulación de la información, reduciendo la invisibilidad científica. Se postula, por ello, un nuevo nivel de trabajo, un nuevo eslabón de conocimiento, un nuevo enfoque. Nuestra revista toma de la historia la esencia de la agricultura de zonas áridas y se proyecta en áreas de creciente interés. IDESIA (del latin Idaea = Idea). consider the rigor and excellence of the journal for which she or he is working. Once the manuscript is accepted, one of the requisites of the scientific method is fulfilled-diffusion of unpublished information. The challenges are growing for IDESIA; there are new information channels, dynamic professional networks where information flows and must respond to the criteria of scientific quality based on the rigor of the review process. IDESIA is available for the publication of international scientific articles; it is included in several databases.

(CAB, SciELO, Dialnet, to name a few). Thus in contrast to the suggestion of Contreras et al.. (2015), the studies are projected outside of Chile, increasing the circulation of the information and reducing "scientific invisibility". This therefore postulates a new level of work, a new step in knowledge, a new focus. Our journal takes the history of the essence of arid zone agriculture and projects it in areas of growing interest. Idesia comes from the latin idaea $=i d e a$ ).

\section{Literatura Citada}

Ganga C., F.; Paredes B., L.; Pedraja-R., L.

2015. Importancia de las publicaciones académicas: algunos problemas y recomendaciones a tener en cuenta. IDESIA, 33 (4): 111-119.
Mc Donald, S., Feather, J.

1995. British library and information science journals: a study of quality control. Jour. of Information Science, 21 (5): 359-369. 